\title{
KARAKTERISTIK BAHASA INDONESIA LOGAT PAPUA DAN RELEVANSINYA SEBAGAI MATERI AJAR MATA KULIAH SOSIOLINGUISTIK DI PROGRAM STUDI PENDIDIKAN BAHASA INDONESIA UNIVERSITAS SEBELAS MARET
}

\author{
Ira Prihapsari, Budhi Setiawan, Edy Suryanto \\ Universitas Sebelas Maret \\ Surel: iraprihapsari@student.uns.ac.id
}

\begin{abstract}
Abstrak: Penelitian ini merupakan penelitian studi kasus. Teknik pengambilan sampel adalah purposive sampling. Sumber data yang digunakan berupa peristiwa, informan, dan dokumen. Teknik pengumpulan data dilakukan dengan observasi langsung, wawancara, dan dokumen. Uji validitas data yang digunakan adalah triangulasi sumber dan triangulasi metode. Teknik analisis data yang digunakan adalah analisis data model alir. Hasil penelitian ini adalah deskripsi tentang: (1) karakteristik bahasa Indonesia logat Papua dibedakan berdasar unsur linguistik dan nonlinguistik. Unsur linguistik meliputi; (a) penggantian fonem; (b) penggantian diftong; (c) pelesapan fonem; (d) penggunaan intonasi. Unsur nonlinguistik berupa peristiwa tutur dan paralinguistik; (2) faktor-faktor yang mempengaruhi munculnya karakteristik bahasa Indonesia logat Papua, yaitu; (a) kesatuan administratif; (b) rasa identitas komunitas yang khusus; (c) tinggal di wilayah geografi yang sama; (d) pengalaman sejarah; (3) bahasa Indonesia logat Papua memiliki relevansi sebagai materi ajar mata kuliah sosiolinguistik di Program Studi Pendidikan Bahasa Indonesia Universitas Sebelas Maret.
\end{abstract}

Kata kunci: karakteristik bahasa Indonesia, logat, sosiolinguistik

\section{CHARACTERISTICS OF THE PAPUA LOGAT INDONESIAN LANGUAGE AND ITS RELEVANCE AS A SOCIOLINGUISTIC LEARNING MATERIAL IN STUDY PROGRAM OF INDONESIAN LANGUAGE EDUCATION SEBELAS MARET UNIVERSITY}

\begin{abstract}
This research is a case study research.. The sampling technique is purposive sampling. Source of data used in the form of events, informants, and documents. Data collection technique used are direction observation, interview, and document. The data validity test used is triangulation of source and triangulation method. Data analysis technique used is flow model. The result of this research is description of: (1) the characteristic Indonesian Papuan dialect are divided into linguistic and nonlinguistic elements. The linguistic elements include; (a) phoneme replacement; (b) diphthong replacement; (c) phoneme removal; (d) the use of intonation. Nonlinguistic elements are speech and paralinguistic events; (2) the factors that influence the emergence of Indonesian Papuan dialect are; (a) administrative unity; (b) a specific sense of community identity; (3) the same of geographical area; (d) historical experience; (3) characteristics of Indonesian Papuan dialect has relevance as materials of sociolinguistic subject at Indonesian Language Education Department of Sebelas Maret University.
\end{abstract}

Keywords: characteristics of Indonesian language, dialect, sociolinguistics

\section{PENDAHULUAN}

Bahasa sebagai bagian dari gejala sosial yang tidak dapat terlepas dari pemakainya. Sumarsono (2011: 2) mengungkapkan bahwa kajian sosiolinguistik menyoroti keseluruhan masalah dengan organisasi sosial perilaku bahasa, tidak hanya mencakup pemakaian bahasa saja, melainkan juga sikap-sikap bahasa, perilaku terhadap bahasa dan pemakaian bahasa. Bahasa dan pemakaian bahasa tidak hanya ditentukan oleh faktorfaktor linguistik, tetapi juga oleh faktorfaktor nonlinguistik, antara lain adalah 
faktor sosial. Di samping itu, pemakaian bahasa juga dipengaruhi oleh faktor-faktor situasional, yaitu: siapa yang berbicara, dengan ragam bahasa apa, kepada siapa, kapan, di mana, dan mengenai masalah apa (Suwito, 1996: 4). Menurut Achmad \&

Abdullah (2012: 9) setiap bahasa digunakan oleh sekelompok orang yang termasuk dalam suatu masyarakat bahasa. Anggota masyarakat suatu bahasa biasanya terdiri dari berbagai orang dengan status sosial dan berbagai latar belakang budaya yang tidak sama. Oleh karena latar belakang dan lingkungannya tidak sama, maka bahasa yang digunakan pun menjadi bervariasi dan beragam.

$$
\text { Bahasa Indonesia dalam }
$$
perkembangannya mendapatkan pengaruh dari berbagai bahasa, baik bahasa daerah maupun bahasa asing. Pemakaian bahasa Indonesia oleh masyarakat Indonesia di berbagai daerah pun juga memiliki kekhasan tersendiri, seperti yang terjadi di Papua. Letaknya yang berada di bagian timur Indonesia, memungkinkan terjadinya variasi pamakaian bahasa Indonesia Adanya variasi logat berbahasa yang dimiliki oleh masyarakat di masing-masing daerah merupakan khazanah kebahasaan di Indonesia. Berikut ini adalah salah satu pemakaian bahasa Indonesia oleh penutur Papua di ranah pendidikan.

Pembicara 1 : Kaka Ira ada panggil $\boldsymbol{k a}$ ? 'Kakak Ira ada yang memanggilkah?'

Pembicara 2 : Bukan 'Bukan'

Pembicara 1 : $\mathbf{S a}$ pu teman yang ini to, Prisila to, dia paling cerewet..e. 'Saya punya teman, namanya Prisila, dia sangat cerewet'

Pembicara 2 : Aku kok gatel ya 'Saya kok gatal-gatal ya?'

Pembicara 1 : $\mathbf{S a}$ juga. Kena uburubur kapa? aih sa tra bisa pake itu 'Saya juga. Apakah saya terkena ubur-ubur? eh, saya tidak bisa pakai itu'

Pembicara 2 : Selain pengembangan diri, kalau ada joget kayak gini, ada apa lagi sih Da? 'Selain joget ada kegiatan apa lagi saat mata pelajaran pengembangan diri di sekolah Eda?

Pembicara 1 : Kalo bukan joget tong pu senam lagi, kalo trada yospan. Kalo...Kalo selain pengembangan diri yang punya apa, macam hobi-hobi, main raket begitu. Begitu tu dong punya. Kalo tong kan lari to. 'Kami punya senam lagi, kalau tidak ya tarian Yospan. Kalau pengembangan diri, mereka bermain sesuai hobi mereka, misalnya ada yang badminton. Kalau saya kan hobi lari"

Data percakapan di atas terdiri dari dua orang pembicara, pembicara 1 adalah siswa kelas VII SMP Negeri 7 Nabire, sedangkan pembicara 2 adalah peneliti. Konteks pembicaraan yang berlangsung adalah keduanya baru saja pulang dari pantai kemudian mereka membicarakan tentang kegiatan pengembangan diri di SMP Negeri 7 Nabire. Berdasarkan percakapan di atas, dapat terlihat pemakaian bahasa Indonesia oleh penutur Papua memiliki kekhasan logat. Kaka artinya 'kakak', dalam hal ini penutur melakukan penanggalan fonem $/ \mathrm{k} /$. Selanjutnya $k a$ memiliki arti 'kah', dalam hal ini penutur melakukan penanggalan fonem $/ \mathrm{h} /$. Penutur melakukan pemendekan kata yang bisa terlihat pada kata 'saya' menjadi $s a$, seperti yang diungkapkan oleh Saragih (2012) yaitu "Saya and sa are used to refer to a 
singular speaker". Ia berpendapat bahwa kata sa dalam bahasa logat Papua digunakan sebagai kata ganti orang pertama. Pemendekan kata juga terjadi pada kata 'punya' menjadi $p u$, Kluge (2015) memaparkan:

"The possessive marker can be represented with long punya, reduced $p u$, clitic $=p$, or a zero morpheme. There are no syntactic or semantic restrictions on the uses of the long and reduced possessive marker forms."

Pernyataan Kluge di atas menerangkan bahwa morfem nol (zero) berarti morfem yang salah satu alomorfnya tidak berwujud bunyi segmental maupun berupa prosodi (unsur segmental) melainkan berupa kekosongan, sehingga tidak ada batasan semantik atau sintaksisnya. Pemendekan juga terjadi pada kata 'itu' menjadi $t u$, kata kitorang menjadi kitong dan direduksi lagi menjadi tong yang berarti 'kita'. Merujuk pada beberapa fenomena bahasa di atas, dapat diketahui bahwa secara morfologi bahasa Indonesia logat Papua mengalami pemendekan kata yang menyebabkan pembentukan kata-kata baru.

Selain itu, penutur Papua juga melakukan pemendekan dua kata, seperti yang terlihat pada kata berikut. ' $K a p a$ ' adalah gabungan antara kata $k a$ dan apa memiliki arti untuk mempertegas kalimat tanya 'kah apa'. Kata tra artinya tidak, sedangkan trada merupakan gabungan dari tra dan ada, bila digabung memiliki arti 'tidak ada'. Kata tra memiliki fungsi membentuk klausa negatif, seperti pendapat Kluge (2015) di bawah ini:

"Negative clauses are formed with the negation adverbs tida/tra 'neg' or bukang 'neg'. Negator tida/tra 'neg' is used for the negation of verbal, existential, and nonverbal prepositional clauses."

Kluge mengungkapkan bahwa kata tra berfungsi sebagai pembentuk klausa negatif yang dapat digunakan pada verba eksistensial dan verba preposisi. Pada contoh percakapan di atas, penutur menggunakan partikel to untuk mempertegas kalimat. Pemakaian bahasa Indonesia logat Papua di atas selaras dengan pendapat Winarti (2017) yang menyatakan bahwa salah satu sifat bahasa adalah tidak tetap, tetapi berkembang atau selalu mengalami perubahan karena berbagai sebab. Perubahan-perubahan mendasar adalah yang cepat atau jelas terlihat, seperti perubahan fonologi, morfologi, sintaksis, ataupun semantis.

Berdasarkan uraian di atas dapat diketahui bahwa penutur Papua menggunakan bahasa Indonesia yang disingkat-singkat untuk berkomunikasi. Fenomena lain dalam berbahasa Indonesia oleh penutur Papua juga terlihat dengan adanya perubahan huruf vokal, yaitu /i/ menjadi /e/ di akhir silabel. Berikut adalah contohnya, air $\rightarrow$ aer; baik $\rightarrow$ bae; main $\rightarrow$ maen. Selain itu ada perubahan vokal /e/ menjadi /a/, contohnya: tebal $\rightarrow$ tabal; berat $\rightarrow$ barat; semua $\rightarrow$ samua; tertawa $\rightarrow$ tatawa.

Fields (2010) mengemukakan bahwa bahasa Papua menggunakan kata bantu kerja untuk menggantikan prefiks. Berikut adalah contohnya, dimarahi menjadi dapat marah, penutur Papua menyebutnya 'dapa mara'. Disusahkan menjadi dapat susah, penutur Papua menyebutnya 'dapa susa' atau 'kena susa'. Membuat kesalahan menjadi bikin salah, penutur Papua menyebutnya 'bikin sala'. Memperpendek menjadi kasih pendek, penutur Papua menyebutnya 'kasi pendek'. Mengurangi menjadi kasih kurang, penutur Papua menyebutnya 'kasi kurang'.

Kekhasan lain yang dimiliki penutur Papua saat berkomunikasi ialah menggunakan partikel dalam berbahasa Indonesia. Adapun partikel yang digunakan ialah eleh, jadi, jih, ka, ne, sampe, dan to. Partikel-partikel tersebut digunakan untuk menunjukkan kalimat tanya, kalimat perintah, penegasan, dan kalimat berita. Misalnya pada kalimat berikut, "Kaka Ira ada panggil ka?". Partikel ka digunakan untuk kalimat tanya. 
Selanjutnya, "Sa pu teman yang ini to, Prisila to, dia paling cerewet..e." partikel to digunakan untuk penegasan pada kalimat berita.

Dalam masyarakat yang multikultural, muncul berbagai ragam bahasa dari kelompok-kelompok sosial tertentu (Lestari, 2013). Fathurrohman, Sumarwati, \& Hastuti (2013) menjelaskan hubungan antara bahasa dan masyarakat dapat dikaji menggunakan teori sosiolinguistik. Hal tersebut selaras dengan pendapat Saddhono (2014: 3) yang menerangkan bahwa kajian sosiolinguistik berkaitan dengan varian-varian bahasa dan korelasinya dengan aspek-aspek sosial yang relevan pada garis besarnya masih benar-benar bersifat linguistik, baik analisis maupun teknik pengumpulan data yang dilakukan secara empiris. Dengan demikian dapat diketahui bahwa variasi pemakaian bahasa oleh masyarakat dikaji dalam mata kuliah sosiolinguistik.

Pemakaian bahasa sehari-hari merupakan identitas bagi masyarakat tertentu dalam lingkungan sosial. Oleh karena itu, pemakaian bahasa oleh masyarakat Papua memiliki kekuatan yang menarik untuk diteliti. Pada penelitian ini, objek yang akan dikaji adalah karakteristik bahasa Indonesia logat Papua dan relevansinya sebagai materi ajar mata kuliah sosiolinguistik di Program Studi Pendidikan Bahasa Indonesia Universitas Sebelas Maret.

\section{METODE PENELITIAN}

Penelitian ini dilaksanakan di beberapa wilayah di Kabupaten Nabire, Provinsi Papua, berikut adalah rinciannya:

(1) Jalan Pemuda, Kelurahan Oyehe, Distrik Nabire; (2) Pasar Tradisional Oyehe; (3) Kantor Dinas Pendidikan Kabupaten Nabire; (4) Balai Kampung Kimi, Distrik Teluk Kimi, Kabupaten Nabire; (5) SMP Negeri 7 Nabire; (6) SD Negeri Boratei.

Penelitian ini bersifat kualitatif deskriptif dengan pendekatan penelitian studi kasus. Data dan sumber data yang digunakan dalam penelitian ini berupa peristiwa, informan, dan dokumen dengan menggunakan teknik purposive sampling. Pengumpulan data dilakukan dengan observasi langsung, wawancara, dan dokumen. Data yang telah terkumpul selanjutnya divalidasi dengan triangulasi metode dan triangulasi sumber. Teknik analisis data yang digunakan adalah analisis data model alir yang meliputi empat tahap, yaitu: (1) pengumpulan data; (2) reduksi data; (3) penyajian data; (4) penarikan simpulan.

\section{HASIL DAN PEMBAHASAN \\ Karakteristik Bahasa Indonesia Logat Papua}

Karakteristik bahasa Indonesia logat Papua dapat dibedakan berdasarkan unsur linguistik dan unsur nonlinguistiknya. Berdasarkan unsur linguistiknya, dapat dianalisis melalui aspek fonologi, morfologi, dan sintaksis. Unsur nonlinguistik dapat dibedakan berdasarkan peristiwa tutur dan paralinguistik.

\section{Fonologi}

Penggantian fonem $/ i / \rightarrow / e /$

Fonem /i/ pada bahasa Indonesia logat Papua tidak dapat dipertahankan bunyinya. Seperti yang tampak pada data berikut ini.

$\begin{array}{lll}\text { /adik/ } & \rightarrow & \text { [ade] } \\ \text { /air/ } & \rightarrow & \text { [aer] } \\ \text { /baik/ } & \rightarrow & \text { [bae] } \\ \text { /balik/ } & \rightarrow & {[\text { bale] }} \\ \text { /gali/ } & \rightarrow & \text { [gale] } \\ \text { /main/ } & \rightarrow & {[\text { [maen] }} \\ \text { /kail/ } & \rightarrow & {[\text { kael] }} \\ \text { /mengalir/ } & \rightarrow & \text { [mengaler] }\end{array}$

Fonem /e/ pada kata ade, aer, bae, bale, gale, maen, kael, mengaler seharusnya diisi oleh fonem /i/. Analisis yang diperoleh berdasarkan data tersebut adalah terjadi penggantian fonem yang disebabkan oleh fonem-fonem lain yang ada di sekitarnya. Fonem /i/ akan digantikan dengan fonem /e/ apabila letaknya berada di dekat konsonan laminoalveolar ( $1, \mathrm{n}, \mathrm{r})$ dan konsonan dorsovelar $(\mathrm{k})$. 


\section{Penggantian fonem $/ e / \rightarrow / a /$}

Pada bahasa Indonesia logat Papua

juga mengenal penggantian fonem /e/ menjadi /a/ seperti yang tampak pada data di bawah ini.

$\begin{array}{lll}\text { /berat/ } & \rightarrow & {[\text { barat] }} \\ \text { /empat/ } & \rightarrow & {[\text { ampat] }} \\ \text { /kecil/ } & \rightarrow & {[\text { kacil] }} \\ \text { /kering/ } & \rightarrow & {[\text { karing] }} \\ \text { /keringat/ } & \rightarrow & {[\text { karingat] }} \\ \text { /ketiak/ } & \rightarrow & {[\text { katiak] }} \\ \text { /semua/ } & \rightarrow & {[\text { samua] }} \\ \text { /tebal/ } & \rightarrow & {[\text { tabal] }}\end{array}$

Berdasarkan data di atas, dapat diketahui bahwa penggantian fonem /e/ menjadi /a/ dapat menyebabkan kerancuan makna atau ambiguitas. Seperti yang terlihat pada kata /berat/ yang dilafalkan [barat] dalam bahasa Indonesia logat Papua. Kedua kata tersebut memiliki makna yang berbeda, /berat/ berarti besaran 'ukuran', sementara /barat/ berarti 'nama mata angin'.

\section{Penggantian fonem $/ n / \rightarrow / y /$}

Penutur bahasa Indonesia logat Papua mengekspresikan bunyi [n] menjadi [y] pada posisi akhir, seperti yang tampak pada data di bawah ini.

$$
\begin{array}{lll}
\text { /hilang/ } & \rightarrow & {[\text { hilan] }} \\
\text { /jaran/ } & \rightarrow & {[\text { jarang] }} \\
\text { /kanan/ } & \rightarrow & {[\text { kanang] }} \\
\text { /kurun/ } & \rightarrow & {[\text { kurung] }} \\
\text { /medan/ } & \rightarrow & {[\text { medang] }} \\
\text { /perang/ } & \rightarrow & \text { [peran] } \\
\text { /sembilan/ } & \rightarrow & {[\text { sembilang] }}
\end{array}
$$

Adanya penggantian fonem tersebut menjadi ambigu apabila tidak memperhatikan konteks bahasa yang digunakan. Perubahan bunyi [n] menjadi [n] atau sebaliknya disebabkan karena fonem $/ \mathrm{n} / \mathrm{dan} / \mathrm{n} /$ merupakan bunyi nasal.
Penggantian diftong [au] $\rightarrow[o]$ dan diftong [ai] $\rightarrow[e]$

Penggantian diftong $[a u]$ menjadi [o] dan diftong $[a i]$ menjadi $[e]$ tampak pada data di bawah ini.

\section{Diftong $[a u]$ menjadi $[o]$}

$$
\begin{array}{lll}
\text { /engkau/ } & \rightarrow & {[\mathrm{ko}]} \\
/ \mathrm{kalau} / & \rightarrow & {[\mathrm{kalo}]} \\
/ \mathrm{pisau} / & \rightarrow & {[\mathrm{piso}]} \\
/ \mathrm{mau} / & \rightarrow & {[\mathrm{mo}]}
\end{array}
$$

\begin{tabular}{lll}
\multicolumn{3}{c}{ Diftong [ai] menjadi $[\boldsymbol{e}]$} \\
/gulai/ & $\rightarrow$ & [gule] \\
/pantai/ & $\rightarrow$ & [pante] \\
/sampai/ & $\rightarrow$ & [sampe] \\
/tapai/ & $\rightarrow$ & [tape]
\end{tabular}

\section{Pelesapan fonem}

Bahasa Indonesia logat Papua mengalami pelesapan fonem $/ \mathrm{h} / \mathrm{dan} / \mathrm{k} /$.

\section{Pelesapan fonem /h/}

$\begin{array}{lll}\text { /hapus/ } & \rightarrow & \text { [apus] } \\ \text { /hisap/ } & \rightarrow & \text { [isap] } \\ \text { /jatuh/ } & \rightarrow & \text { [jato] } \\ \text { /indah/ } & \rightarrow & \text { [inda] } \\ \text { /merah/ } & \rightarrow & \text { [mera] } \\ \text { /tanah/ } & \rightarrow & \text { [tana] } \\ \text { /rumah/ } & \rightarrow & \text { [ruma] } \\ \text { /panah/ } & \rightarrow & \text { [pana] } \\ \text { /buluh/ } & \rightarrow & \text { [bulu] } \\ \text { /hitung/ } & \rightarrow & \text { [itung] } \\ \text { /hidup/ } & \rightarrow & \text { [idop] } \\ \text { /lidah/ } & \rightarrow & \text { [lida] }\end{array}$

\section{Pelesapan fonem $/ \mathrm{k} /$}

$\begin{array}{lll}\text { /banyak/ } & \rightarrow & {[\text { banya] }} \\ \text { /bengkak/ } & \rightarrow & {[\text { bangka] }} \\ / \text { duduk/ } & \rightarrow & {[\text { dudu] }} \\ / \text { garuk/ } & \rightarrow & {[\text { garu] }} \\ \text { /gosok/ } & \rightarrow & {[\text { goso] }} \\ / \text { pendek/ } & \rightarrow & {[\text { pende] }} \\ / \text { bapak/ } & \rightarrow & {[\text { bapa] }} \\ / \text { kakak/ } & \rightarrow & {[\text { kaka] }} \\ / \text { nenek/ } & \rightarrow & {[\text { nene] }} \\ / \text { cobek/ } & \rightarrow & {[\text { cobe] }}\end{array}$


Berdasarkan data di atas, diketahui bahwa pelesapan fonem $/ \mathrm{h} /$ terjadi apabila letaknya berada di awal maupun di akhir kata, sedangkan pelesapan fonem $/ \mathrm{k} /$ terjadi apabila letaknya di akhir kata. Tujuan pelesapan yaitu untuk memperoleh kepraktisan berbahasa. Kepraktisan berbahasa berfungsi agar bahasa yang digunakan lebih singkat, padat, dan dimengerti dengan cepat. Pelesapan fonem /h/ dan /k/ disebabkan karena kedua fonem tersebut dihasilkan oleh artikulator yang jaraknya berdekatan, yaitu fonem $/ \mathrm{h} /$ dihasilkan oleh faringal dan fonem / $/ \mathrm{k} /$ dihasilkan oleh dorsovelar.

\section{Intonasi}

Masyarakat Papua menggunakan intonasi untuk menandai tingkatan bahasa (speech level). Misalnya, seseorang yang berbicara dengan teman sebaya, maka intonasi yang digunakan adalah cepat dan keras. Jika seseorang berbicara dengan mitra tutur yang dihormati atau usianya lebih tua, maka intonasi yang digunakan rendah dan pelan. Permainan intonasi bahasa oleh masyarakat Papua untuk menunjukkan tingkat kesantunan berbahasa.

\section{Morfologi}

\section{Partikel Bahasa}

Partikel bahasa yang digunakan adalah: eleh, jadi, jih, ka, ne, sampe, dan to. Berikut adalah pemaparannya.

Partikel eleh dalam bahasa Indonesia logat Papua berfungsi penegasan dalam kalimat. Berikut contohnya:

"Pak Samberi juga lancar basa

Jawa e"

'Pak Samberi juga lancar berbahasa Jawa'

"Eh, ko pi makan sana!"

'Kamu makan dulu sana!'

Partikel jadi dalam bahasa Indonesia logat Papua berfungsi untuk memberi penegasan dalam kalimat. Berikut contohnya:
"Bentar ya Kak, masih makan di luar jadi"

'Sebentar Kak, saya masih makan di luar (di warung makan)'

"Kalian di mana jadi?"

'Kalian di mana?'

Partikel jih di awal kalimat berfungsi sebagai seruan elakan pernyataan sebelumnya. Berikut contohnya:

"Jih, sa tra ambil ko pu buku. Ko pu buku tu su taro di situ memang"

'Saya tidak mengambil bukumu. Bukumu memang diletakkan di situ'

"Jih..ini baju lama kok. Ko saja yang baru lihat"

'Ini baju lama. Kamu saja yang baru melihat'

Partikel $k a$ berungsi untuk membentuk kalimat tanya dan menggantikan makna "atau". Partikel ka biasanya diletakkan di belakang kalimat, memiliki fungsi pembentuk kalimat tanya. Partikel ka yang diletakkan di antara dua pilihan/di tengah kalimat, memiliki arti yang sama dengan kata "atau". Di bawah ini adalah contohnya:

"Kak su makan ka?"

'Kakak sudah makan?'

"Tiga bulan $\boldsymbol{k} \boldsymbol{a}$ enam bulan?"

'Tiga bulan atau enam bulan?'

Partikel ne dalam bahasa Indonesia logat Papua memiliki beberapa fungsi, berikut adalah pemaparannya.

(1) Letaknya di awal kalimat, maka sebagai kata seru untuk menyapa, menegur, atau mengingatkan lawan bicara. Contoh:

"Ne, sa su bilang ko"

" $H e$, saya sudah bilang kepadamu'

(2) Memiliki kesamaan arti dengan kata "ini", berikut contohnya: "Ada pemeriksaan tiket ne dari ujung ke ujung tu lari tu." 
'Ada pemeriksaan tiket ini, dari ujung sampai ke ujung, lalu kita lari'

(3) Memunculkan pertanyaan balik, contoh:

"Tra tahu jalan kembali ne"

'Tidak tahu jalan kembali ini'

"Aduh, sa ada PR tidak ne?"

'Aduh, saya ada PR tidak ya?'

(4) Mempertegas kalimat. Berikut contohnya:

"Kaka jang lupa bawa kain ne"

'Kakak jangan lupa bawa kain'

Partikel sampe digunakan untuk memberikan makna penyangatan dalam kalimat. Berikut contohnya:

"Aduh sa hati ni setengah mati sampe"

'Aduh, hati ini susah'

"Dosen ini de kasi tugas susah sampe, sa tra bisa kerjakan"

'Dosen ini memberi tugas susah sekali, saya tidak bisa mengerjakan'

Partikel to partikel to berfungsi untuk memberi penegasan dalam kalimat. Pada umumnya, partikel to digunakan ketika menyampaikan ide, pendapat, atau opini untuk menekankan kebenaran dari informasi yang disampaikan oleh penutur.

"Pada dasarannya anak punya gambaran to"

'Pada dasarnya anak mempunyai gambaran'

\section{Pelesapan Afiks}

Pemakaian bahasa Indonesia logat Papua mengalami pelesapan afiks. Adapun pelesapan terjadi pada afiks $m e$ - dan ter-, seperti yang tampak pada contoh di bawah ini.

"Sa buat mereka baku lomba cari"

'Saya membuat mereka saling mencari'
"Baru kita cari, kena nyamuk"

'Baru kita mencari, terkena nyamuk'

"Baru kita cari, kena nyamuk"

'Baru kita mencari, terkena nyamuk'

\section{Pemakaian Kata Bantu Kerja sebagai Pengganti Prefiks}

Kata bantu kerja kasi digunakan untuk menggantikan prefiks meng- dan $d i-$ pada pemakaian bahasa Indonesia logat Papua, seperti yang tampak pada data di bawah ini.

"Pertama tu kita cari, ambil parang,

kasi rubuh ke bawah..."

'Pertama, kita cari, ambil parang,

merubuhkan ke bawah...'

$$
\begin{aligned}
& \text { "Sa mau kasi kembali tapi } \\
& \text { bagaimana" } \\
& \text { 'Saya mau mengembalikan tapi } \\
& \text { bagaimana' } \\
& \text { "Baru cuci di air, trus baru kasi kikis } \\
& \text { lagi” } \\
& \text { 'Baru cuci di air, lalu dikikis lagi' } \\
& \text { “...dia punya kotoran kasi buang } \\
& \text { dengan pisau” } \\
& \text { '...kotorannya dibuang dengan } \\
& \text { pisau' }
\end{aligned}
$$

\section{Kontraksi (Pemendekan Kata)}

Pemakaian bahasa Indonesia logat Papua mengalami penyingkatan atau pemendekan. Hal ini terjadi karena penutur ingin menggunakan bahasa yang cepat dan ringkas. Pemendekan kata berupa pengucapan suku kata depan, pengucapan suku kata terakhir, dan meringkas dua kata dasar.

Tabel 1. Pemendekan dengan Penghilangan Suku Kata di Belakang

\begin{tabular}{cc}
$\begin{array}{c}\text { Bahasa Baku } \\
\text { Indonesia }\end{array}$ & $\begin{array}{c}\text { Bahasa Indonesia } \\
\text { Logat Papua }\end{array}$ \\
\hline dari & dar \\
dengan & deng \\
jangan & jang
\end{tabular}




\begin{tabular}{cc} 
kamu & kam \\
kasih & kasi/kas \\
pergi & pi \\
punya & pu \\
saya & sa \\
sudah & su \\
tidak & tra \\
\hline
\end{tabular}

Tabel 2. Pemendekan dengan Penghilangan Suku Kata di Depan

\begin{tabular}{|c|c|}
\hline $\begin{array}{c}\text { Bahasa Baku } \\
\text { Indonesia }\end{array}$ & $\begin{array}{c}\text { Bahasa } \\
\text { Indonesia Logat } \\
\text { Papua } \\
\end{array}$ \\
\hline ada & $\mathrm{da}$ \\
\hline ini & ni \\
\hline itu & $\mathrm{tu}$ \\
\hline
\end{tabular}

Gejala pemendekan kata pada pemakaian bahasa Indonesia logat Papua juga terjadi melalui penyingkatan dua kata yaitu kata trada. Kata trada berarti "tidak ada". Berasal dari penyingkatan antara kata "tidak" dan "ada".

\section{Sintaksis}

Kekhasan lain yang dimiliki bahasa Indonesia logat Papua terdapat dalam konstruksi frasa kepemilikan. Bahasa Indonesia logat Papua menambahkan kata pu sebagai penanda kepemilikan dalam kalimat. Kalimat "tempat praktik kalian" dalam bahasa Indonesia baku berubah menjadi "kalian pu tempat praktek" dalam bahasa Indonesia logat Papua. Konstruksi frasa kepemilikan dalam bahasa Indonesia baku berupa termilik + pemilik, sedangkan frasa kepemilikan dalam bahasa Indonesia logat Papua berupa pemilik + penanda kepemilikan + termilik. Berikut contohnya:

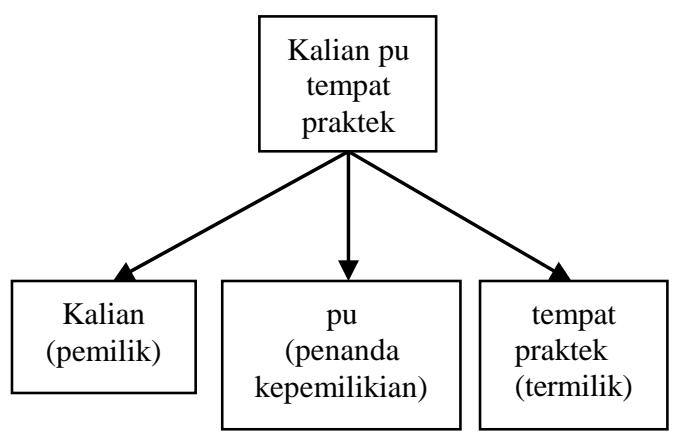

Berdasarkan diagram di atas, diketahui bahwa kata "kalian" menduduki fungsi sebagai pemilik, kata "pu" sebagai penanda kepemilikan, dan kata "tempat praktek" menduduki fungsi sebagai termilik.

Contoh lain yaitu pada kalimat "sa pu tete" yang berarti "kakek saya". Konstruksi frasa kepemilikan akan sebagai berikut:

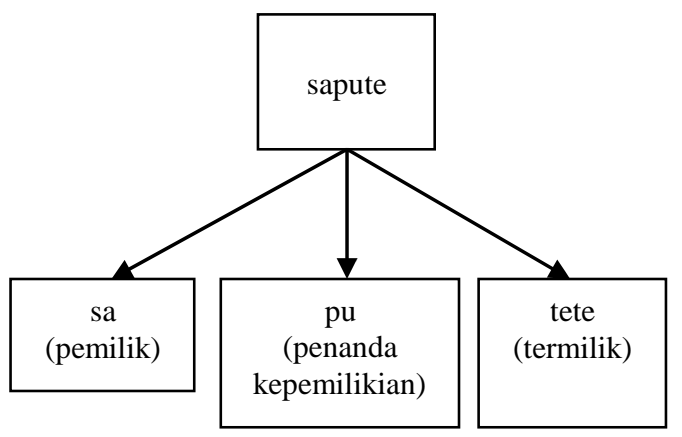

Kata "sa" yang berarti "saya", menduduki fungsi sebagai pemilik. Kata "pu" yang berarti "punya", berfungsi sebagai penanda kepemilikan, dan kata "tete" yang berarti "kakek" berfungsi sebagai termilik.

\section{Peristiwa Tutur}

Peristiwa tutur dalam penelitian ini menurut teori Hymes yang menyebutkan dalam akronim SPEAKING, yaitu: (1) tatar (setting and scene); (2) peserta (participant); (3) hasil (ends); (4) amanat (squense); (5) cara (key); (6) sarana (instrumentalities); (7) norma (norms); (8) jenis (genres).

\section{Paralinguistik}

Dalam percakapan lisan masyarakat Papua khususnya di Kampung Kimi ditunjukkan keadaan emosi dan sikap melalui gerak-gerik, mimik, keramahan, dan kelantangan dalam berbicara. Penutur sering menggunakan gerakan tangan untuk memperkuat pernyataan maksud tuturan. Misalnya, pada tuturan "kasi toki-toki", mitra tutur yang berasal dari luar Papua tidak memahami maksudnya sehingga penutur menunjukkan gerakan tangan memukul. Toki-toki dalam bahasa Indonesia berarti pukul-pukul. Selain gerakan tangan, masyarakat juga sering 
menggunakan anggukan untuk menyetujui suatu pernyataan.

Faktor yang Mempengaruhi Munculnya Karakteristik Bahasa Indonesia Logat Papua

Berikut adalah faktor-faktor yang mempengaruhi munculnya karakteristik bahasa Indonesia logat Papua.

\section{Kesatuan Administratif}

Pulau Papua terjadi pemekaranpemekaran wilayah, adanya pemekaran tersebut mempengaruhi pembagian wilayah administrasi pemerintahan. Hal tersebut juga mempengaruhi sebaran pemakaian oleh masyarakat. Papua juga mengenal adanya hak ulayat, yaitu pembagian wilayah berdasarkan hukum adatnya. Adanya pembagian wilayah tersebut tentu berpengaruh pada intensitas pemakaian bahasa di wilayah tertentu oleh komunitas masyarakat tertentu saja.

\section{Rasa Identitas Komunitas yang Khusus}

Masyarakat Papua dapat dibedakan menjadi tiga, yaitu: (1) masyarakat pesisir pantai; (2) masyarakat pegunungan; (3) dan masyarakat pendatang. Masyarakat pesisir pantai dan pegunungan merupakan masyarakat asli Papua. Meskipun sesama masyakarakat asli Papua, tampak ada perbedaan di antara mereka. Selain itu, meskipun sesama masyarakat asli Papua namun mereka memilik beragam bahasa yang berbeda. Perbedaan mencolok yaitu pemakaian intonasi bahasa. Saat berbicara, masyarakat pesisir pantai cenderung memiliki intonasi yang rendah dan tidak terlalu cepat, sementara masyarakat pegunungan menggunakan intonasi berbicara yang cepat. Bahasa Indonesia yang digunakan oleh masyarakat pendatang pun juga berbeda-beda, ada yang menggunakan bahasa Indonesia logat Jawa, ada bahasa Indonesia logat Bugis, bahasa Indonesia logat Toraja, dan masih banyak lainnya.

\section{Kesamaan Wilayah Geografi}

Variasi berbahasa dipengaruhi oleh perbedaan daerah secara geografis maupun ekologinya. Masyarakat Kampung Kimi tinggal di wilayah pesisir pantai, sesuai ekologinya mata pencaharian yang dilakukan oleh sebagian besar masyarakat adalah menangkap ikan dan berladang. Masyarakat yang mata pencaharian utamanya menangkap ikan, memiliki kekhasan berbahasa yaitu dalam menunjukkan tempat yang letaknya jauh dari pantai maka masyarakat menyebutnya "darat" sedangkan tempat yang menunjukkan lokasi dekat dengan pantai maka masyarakat menyebutnya "laut". Berikut adalah contohnya.

Termasuk Brian juga ke darat itu, pulang de menangis-menangis. Mama: "bikin apa?". Adooh.. ingat kakak dorang kitong ke posko darat itu tidak ada kakak dorang yang bikin rame baru tidak ada lalu tempat sepi.

Balai Kampung Kimi diganti menggunakan kata darat karena letaknya lebih jauh dari pantai dibanding jarak rumah warga ke pantai.

\section{Pengalaman Sejarah}

Papua pernah dijajah oleh Jepang. Penjajahan Jepang terhadap Papua adalah untuk merampas hasil minyak bumi sebagai bahan bakar kendaraan perang Jepang. Adanya penjajahan oleh Jepang juga berpengaruh pada pemakaian bahasa yang digunakan oleh masyarakat. Bahasa yang digunakan oleh masyarakat Papua akan terkontaminasi dengan bahasa yang digunakan oleh penjajah. Hal tersebut dikarenakan intensitas pemakaian bahasa digunakan dalam waktu bersamaan dan frekuensi yang tinggi.

Masuknya penjajah Jepang ke Papua melalui jalur laut, menimbulkan intensitas komunikasi masyarakat di pesisir pantai lebih tinggi dibanding masyarakat di pegunungan. Pemakaian bahasa Indonesia logat Papua mengenal berbagai partikel bahasa, antara lain: eleh, jadi, jih, ka, ne, sampe, dan to. Partikel bahasa yang 
terdapat dalam bahasa Indonesia logat Papua memiliki beberapa kesamaan dengan partikel dalam bahasa Jepang. Bahasa Jepang menggunakan partikel $w a$, mo, no, o, ga, ni, e, to, ya, made \& made ni, ka, yori, shika, dake, ne. Terdapat beberapa kesamaan partikel antara pemakaian bahasa Indonesia dan bahasa Jepang yaitu partikel $e, k a$, ne, dan to. Persamaan pemakaian dapat diamati pada tabel berikut.

Tabel 3. Persamaan Partikel Bahasa Indonesia Logat Papua dengan Bahasa Jepang

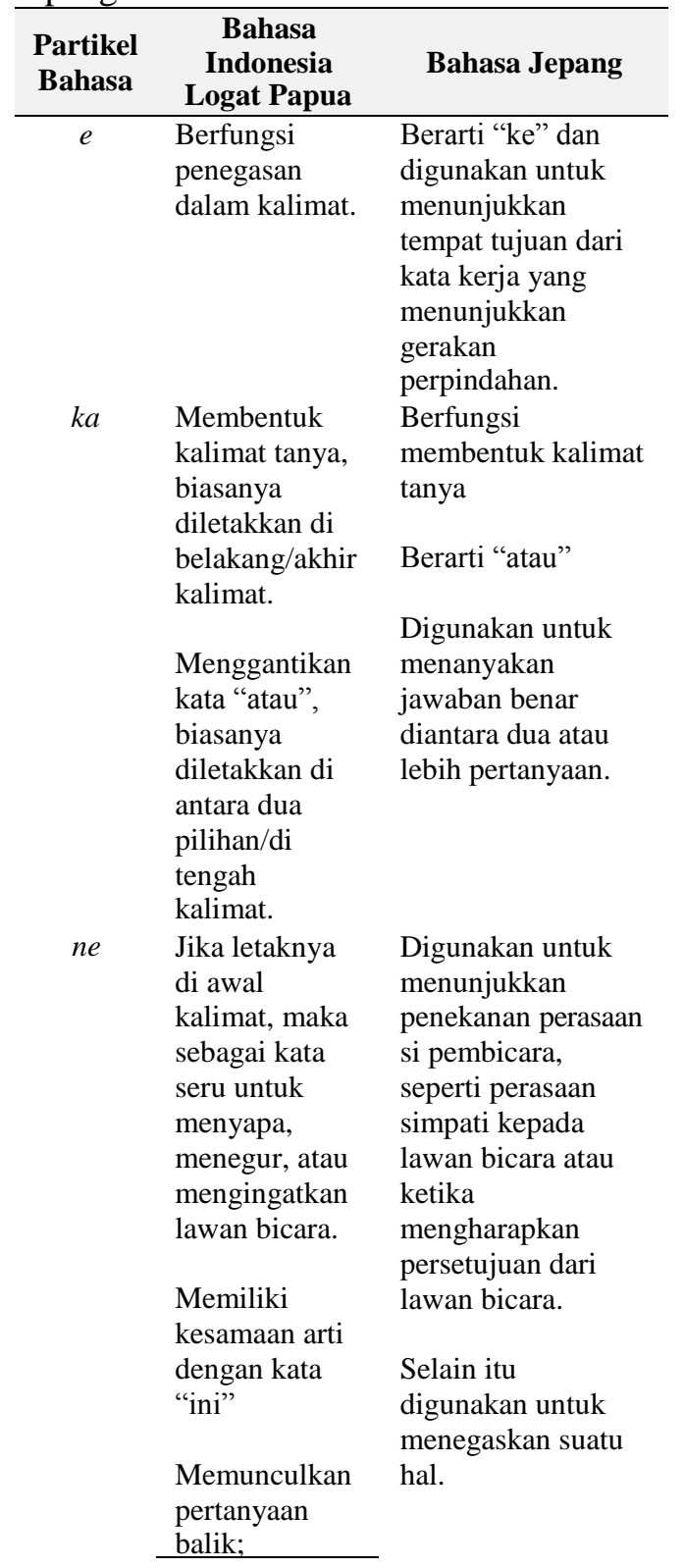

Untuk

mempertegas

kalimat.

to $\quad$ Partikel to

berfungsi

untuk memberi

penegasan

dalam kalimat.

Pada

umumnya, Dipakai setelah kata

partikel to benda

digunakan (orang/binatang)

ketika dapat berarti

menyampaikan "bersama/dengan”.

ide, pendapat,

atau opini

untuk

menekankan

kebenaran dari

informasi yang

disampaikan

oleh penutur.

\section{Relevansi Bahasa Indonesia Logat Papua sebagai Materi Ajar Mata Kuliah Sosiolinguistik}

Hasil penelitian ini sesuai dengan materi yang diajarkan dalam mata kuliah sosiolinguistik, yaitu ragam bahasa dan variasi bahasa. Karakteristik pemakaian bahasa Indonesia logat Papua merupakan salah satu variasi bahasa yang digunakan oleh masyarakat etnis lain, di dalamnya juga ditemukan campur kode yaitu bahasa Indonesia dan bahasa pergaulan sehingga muncul adanya bahasa Indonesia logat Papua. fenomena kebahasaan dan variasi bahasa yang digunakan dalam masyarakat merupakan objek kajian dari sosiolinguistik.

Sosiolinguistik adalah salah satu mata kuliah wajib yang ditempuh di semester lima Program Studi Pendidikan Bahasa Indonesia. Dosen harus membuat Rancangan Pembelajaran Semester (RPS) pada setiap mata kuliah. Salah satu prinsip pengembangan RPS adalah dengan mempertimbangkan karakteristik mahasiswa yang ada dalam program studi tersebut. Setiap tahun mahasiswa memiliki karakter yang berbeda-beda, perbedaan karakteristik tersebut tampak pada latar belakang sosial, ekonomin, dan budaya 
mahasiswa. Keragaman karakteristik mahasiswa di Program Studi Pendidikan Bahasa Indonesia inilah yang menjadi dasar pengembangan RPS, yang tentunya berkaitan dengan bahan ajar. Bahan ajar mata kuliah sosiolinguistik dapat dikembangkan sesuai karakteristik mahasiswa dan ketersediaan bahan ajar. Hasil penelitian pemakaian bahasa Indonesia logat Papua dapat dijadikan sebagai alternatif bahan ajar mata kuliah sosiolinguistik pada kajian jenis objek hubungan bahasa budaya masyarakat, di dalamnya dipelajari mengenai jenis objek hubungan bahasa budaya masyarakat dengan bahasa budaya etnis lain.

\section{SIMPULAN}

Secara ringkas simpulan hasil penelitian ini dapat dirumuskan sebagai berikut. Pertama, karakteristik bahasa Indonesia logat Papua dapat diamati berdasarkan unsur linguistik dan nonlinguistiknya. Berdasarkan unsur linguistiknya ditemukan karakteristik pada aspek fonologi, morfologi, dan sintaksis. Pada aspek fonologi ditemukan: penggantian fonem $/ i /$ menjadi / $e /$; fonem le/ menjadi $/ a /$; fonem $/ n /$ menjadi $/ \eta /$;

\section{REFERENSI}

Achmad, HP \& Abdullah, Alek. (2012). Linguistik Umum. Jakarta: Erlangga.

Fathurrohman, Helmi Rian; Sumarwati; Hastuti, Sri. (2013). Bentuk dan Fungsi

Campur Kode dan Alih kode pada Rubrik 'Ah... Tenane' dalam Harian Solopos, Jurnal Basastra, 2 (1), 1-17. Diperoleh pada 11 Maret 2018, pukul 09:08 WIB, dari http://jurnal.fkip.uns.ac.id/index.php /bhs_indonesia/article/view/2141.

Fields, Phil. (2010, September). Papuan Colloqial Indonesian. Summer Institute of Linguistics International, hlm. 6. Diperoleh pada 9 November 2017, pukul 22:05 WIB, dari https://www.bahasakita.com/wp- penggantian diftong $[a u]$ menjadi $[o]$ dan diftong $[a i] \rightarrow[e]$; pelesapan fonem $/ \mathrm{h} /$ dan $/ \mathrm{k} /$; dan variasi intonasi. Selanjutnya, pada aspek morfologi, ditemukan pemakaian partikel bahasa yaitu partikel eleh, jadi, jih, ka, ne, sampe, dan to. Selain partikel bahasa, ditemukan juga pelesapan afiks, pemakaian kata bantu kerja sebagai pengganti prefiks, dan kontraksi (pemendekan kata). Pada aspek sintaksis ditemukan konstruksi frasa kepemilikan sebagai berikut: pemilik + penanda kepemilikan + termilik. Bahasa Indonesia logat Papua berdasarkan unsur nonlinguistiknya ditemukan karakteristik pada peristiwa tutur dan aspek paralinguistik. Kedua, faktor yang mempengaruhi munculnya karakteristik bahasa Indonesia logat Papua adalah kesatuan administratif, rasa identitas komunitas yang khusus, kesamaan wilayah geografi, dan pengalaman sejarah. Ketiga, bahasa Indonesia logat Papua memiliki relevansi sebagai materi ajar mata kuliah sosiolinguistik. Selain itu, penelitian ini dapat dijadikan alternatif sebagai bahan ajar mata kuliah sosiolinguistik di Program Studi Pendidikan Bahasa Indonesia Universitas Sebelas Maret.

content/uploads/2013/12/ColloquialPapuan-silewp2010-005.pdf.

Kluge, Angela. (2015). A Grammar of Papuan Malay. Jurnal Wacana, 16 (1), 211-232. Diperoleh pada 31

Januari 2018, pukul 01:36 WIB, http://wacana.ui.ac.id/index.php/wjh i/article/view/373/348.

Lestari, Prembayun Miji. (2013). Bahasa Anak-anak Jalanan: Relevansinya dengan Budaya Multikultural Masa Kini Kajian Sosiolinguistik). Jurnal Lingua, 9 (1), 30-38. Diperoleh pada 11 Maret 2018, pukul 09:02 WIB, dari https://journal.unnes.ac.id/ artikel_nju/lingua/2590. 
Rohmadi, M., Sugiri, E., \& Nugraheni, A. S. (2014). Belajar Bahasa Indonesia: Upaya Terampil Berbicara dan Menulis Karya Ilmiah. Surakarta: Cakrawala Media.

Saragih, Chrisma Fernando. (2012). The Practical Use of Person Reference in Papuan Malay, Thesis tidak dipublikasikan, Linguistik

Department Radbound University Nijmegen. Diperoleh pada 11

Februari 2018, pukul 07:21 WIB, https://www.google.co.id/url?sa=t\&s ource=web\&rct=j\&url=http://www.r u.nl/publish/pages/518697/thesis_th e_practical_use_of_person_referenc e_in_papuan_malay.docx\&ved $2 a h U$
KEwiNmsmLh8_ZahWEzbwKHWg oBPMQFjAAegQICBAB\&usg=AO vVawOYA57j3js9g_mePCDhwr0T. Sumarsono. (2011). Sosiolinguistik. Yogyakarta: Sabda.

Suwito. (1996). Sosiolinguistik. Surakarta: UNS Press.

Winarti, Sri. (2017). Sistem Bilangan Beberapa Bahasa di Papua, NTT, dan Maluku Utara. Jurnal Ranah, 6 (2), 235-257. Diperoleh pada 21 Januari 2018, pukul 07:35 WIB, https://www.sil.org/system/files/ reapdata/11/39/34/11393474023119 5199909671254705958986911/enr Emem_survey_report_sections_and _wordlists.pdf. 